\title{
Pilot study in neonates using low-level laser therapy in the immediate postoperative period of myelomeningocele
}

\author{
Estudo piloto em neonatos utilizando o laser de baixa intensidade no pós-operatório imediato \\ de mielomeningocele
}

\author{
Nathali Cordeiro Pinto ${ }^{1}$, Fernando Campos Gomes Pinto ${ }^{2}$, Eduardo Joaquim Lopes Alho ${ }^{3}$, Elisabeth Matheus \\ Yoshimura $^{4}$, Vera Lucia Jornada Krebs ${ }^{5}$, Manoel Jacobsen Teixeira ${ }^{6}$, Maria Cristina Chavantes ${ }^{7}$
}

\begin{abstract}
Objective: To analyze the tissue repair behavior after corrective surgical incision in neonates submitted to low-level laser therapy, in an attempt to diminish the incidence of postoperative dehiscence following the surgery for myelomeningocele performed immediately after birth. Methods: It is a prospective pilot study with 13 myelomeningocele patients submitted to surgery at birth who received adjuvant treatment with low-level laser therapy (Group A). Diode laser C.W., $\lambda=685 \mathrm{tmm}, \mathrm{p}=21 \mathrm{~mW}, E=0.19$ $\mathrm{J}$ was punctually applied along the surgical incision, summing up 4 to $10 \mathrm{~J}$ energy delivered per patient, according to the surgical wound area and, then, compared with the previous results, which were obtained from 23 patients undergoing surgery without laser therapy (Group B). Results: This pilot study showed a significant decline in dehiscence of surgical wounds in neonates submitted to low-level laser therapy as compared to controls (7.69 versus $17.39 \%$, respectively), demonstrating this is an effective, safe and noninvasive treatment method. Conclusion: This new adjuvant therapeutic proposal with low-level laser therapy aided healing of surgical wounds, preventing morbidities, as well as decreasing hospital stay, which implies cost of reduction for patients and for the institution.
\end{abstract}

Keywords: Infant, newborn; Congenital, hereditary, and neonatal diseases and abnormalities/surgery; Laser therapy, low-level; Surgical wound dehiscence/ prevention \& control; Meningomyelocele/surgery; Guided tissue regeneration/methods; Postoperative complications

\section{RESUMO}

Objetivo: Analisar o comportamento da reparação tecidual de incisão cirúrgica corretiva em neonatos submetidos ao laser de baixa intensidade, auxiliando a redução de incidência de deiscência pós-operatória de correção cirúrgica de mielomeningocele realizada imediatamente após o nascimento. Métodos: Estudo piloto, prospectivo, com 13 pacientes operados ao nascimento de mielomeningocele e submetidos ao laser de baixa intensidade como adjuvante. Foi aplicado, ao longo da incisão cirúrgica, o laser de diodo C.W., $\lambda=685 \mathrm{~nm}, \mathrm{p}=21 \mathrm{~mW}$, com E $=0,19 \mathrm{~J}$ por ponto, totalizando valores de energia entregue por paciente entre 4 e 10 $\mathrm{J}$, de acordo com a área da cicatriz cirúrgica, e comparando com os resultados obtidos previamente de 23 pacientes operados sem a terapia com o laser (Grupo B). Resultados: Este estudo revelou significativa redução de deiscências no pós-operatório de neonatos, quando submetidos ao laser de baixa intensidade comparados ao controle $(7,69$ versus $17,39 \%$, respectivamente), evidenciando ser um método de tratamento eficaz, seguro e não-invasivo. Conclusão: Esta nova proposta terapêutica adjuvante com 0 laser de baixa intensidade auxiliou na reparação tecidual da ferida operatória, evitando morbidades, além de diminuir o tempo de internação, sinalizando possível redução de custos tanto para os pacientes quanto para a instituição.

Descritores: Recém-nascido; Doenças congênitas, hereditárias e neonatais e anormalidades/cirurgia; Terapia a laser de baixa intensidade; Deiscência da ferida operatória/prevenção e controle; Meningomielocele/cirurgia; Regeneração tecidual guiada/métodos; Complicações pós-operatórias

\footnotetext{
Study carried out at Unidade Neonatal e Departamento de Neurocirurgia do Hospital das Clínicas da Faculdade de Medicina da Universidade de São Paulo - USP, São Paulo (SP), Brazil.

1 Doctorate student of Instituto do Coração at Hospital das Clínicas da Faculdade de medicina da Universidade de São Paulo - USP, Sao Paulo, (SP), Brazil.

${ }^{2}$ PhD, Neurosurgeon of Hospital das Clinicas da Faculdade de Medicina da Universidade de São Paulo - USP, Sao Paulo (SP), Brazil.

${ }^{3}$ Doctorate Student at Universidade de Würzburg - Germany

${ }^{4}$ Associate Professor at Nuclear and Physical Department at Instituto de Física da Universidade de São Paulo - USP, Sao Paulo (SP), Brazil.

${ }^{5}$ PhD, MD, Neonate Intensive Care at Instituto da Criança do Hospital das Clínicas da Faculdade de Medicina da Universidade de São Paulo, Sao Paulo (SP), Brazil.

${ }^{6} \mathrm{PhD}$, Full Professor of Division of Neurosurgery at Neurology Department at Faculdade de Medicina da Universidade de São Paulo - USP, São Paulo (SP), Brazil.

7 Professor and Executive Chief of Medical Laser Center at Instituto do Coração do Hospital das Clínicas da Faculdade de Medicina da Universidade de São Paulo, São Paulo (SP), Brazil. Corresponding author: Nathali Cordeiro Pinto - Rua Dr. Eneas de Carvalho Aguiar - Cerqueira Cesar - CEP 05403-900 - São Paulo (SP), Brasil - Tel.: 11 3069-5233 - e-mail: nathalicordeiro@ @otmail.com 


\section{INTRODUCTION}

Myelomeningocele (MMC) is the most prevalent form of neural tube malformation, a condition in which incomplete closure of the embryonic neural tube occurs. It is one of the most disabling congenital malformations, accounting for $75 \%$ of cases, with higher incidence in the lumbar and/or sacral regions ${ }^{(1)}$. At the Neonatal Intensive Care Unit (NICU) at Hospital das Clínicas of Faculdade de Medicina of Universidade de São Paulo (HC/FMUSP), from July 2005 to December 2006 (18 months), a total of 3,072 live newborns were admitted, whose incidence of neurosurgical congenital diseases was $1.14 \%$, with $\mathrm{MMC}$ representing $0.36 \%$ with a total of 11 cases treated with surgery soon after birth.

Several considerations were made regarding the best timing for surgical repair aiming to reduce complications, especially dehiscences, fistulae and infections. At the present service, the surgical "time zero" (immediately after birth) showed the lowest rate of dehiscence, $13 \%$ compared to $29 \%$, when the procedure was performed up to 48 hours after birth ${ }^{(2)}$. Despite these good results, the rate of postoperative dehiscence is still high, especially when taking into account its poor consequences (cerebrospinal fluid fistula, meningitis, etc.).

In the study by Filgueiras and Dytz ${ }^{(1)}$, cerebrospinal fluid fistula was the most prevalent postoperative complications with a total of 50 cases $(16.5 \%)$, followed by wound dehiscence with 30 cases $(9.9 \%)$ and infection of surgical wound with 23 (7.6\%). Ventriculitis, sepsis and scoliosis accounted for 38 cases $(12.5 \%)$.

Low-level laser therapy (LLLT) started being used at Instituto do Coração (InCor) a few years ago to aid the healing process of cardiac wounds and it proved, concomitantly, to provide efficient anti-inflammatory and analgesic responses. Several studies employing this method pointed to the efficacy of LLLT in tissue repair immediately after cardiovascular and orthopedic surgeries $^{(3)}$. Laser therapy is able to prevent formation of postoperative dehiscence and it leads to faster functional recovery, thus reducing the duration of hospital stay ${ }^{(4-9)}$. Its preventive use is noninvasive, painless and safe; additionally, it is an easy method to be used without the need of touching the lesion and can be performed at the hospital nursery.

Medical literature has shown good results both in in vitro and in vivo research, with the use of LLLT. In the last few decades, its use has been increasing with studies about the effects of this irradiation in biological function and the doubts have been clarified, to favor analgesia and heal both in animals and in humans ${ }^{(10,11)}$. The literature demonstrates three potential levels of interactions, considering several aspects of phototherapy: molecular, cellular and organic. Karu ${ }^{(12)}$ described that LLLT is responsible for photophysical, photochemical and/or photobiological effects in cells and target tissues.

It is known today that this treatment modality helps in the resolution of inflammatory process with tissue repair of surgical wound by means of photobiomodulation of the tissues operated ${ }^{(13)}$. In previous studies, these benefits were also observed in surgical patients of several age groups who received the same treatment ${ }^{(4-9)}$. The interaction of electromagnetic radiation takes place especially in a medium where unstable redox status is present (typical in situations of physiological stress), with stimulation of certain photoacceptor molecules existing both in the cell membrane and in the internal crest of mitochondrial membrane, and able to aid the damaged tissue to reach tissue homeostasis.

The literature is scarce on the use of LLLT in children and neonates. In the studies performed by Ailioaie ${ }^{(14-15)}$, children were evaluated and treated with exceptional improvement after laser therapy. However, no other reports were found in the literature, especially about the preventive use of LLLT in postoperative wounds in neonates.

\section{OBJECTIVE}

This study intended to evaluate the healing performance of surgically corrected myelomeningocele preventively submitted to local therapy with low-level laser therapy in the immediate postoperative period, in an attempt to reduce complications, aiming to assist in tissue repair and to decrease the incidence of postoperative dehiscence in neonates.

\section{METHODS}

This project was analyzed and approved (Research Protocol \# 0576/09) by the Ethics Committee of HC/ FMUSP. Parents of all the patients with MMC in this study read and signed the institution informed consent form.

The study was conducted at the Neonatal Unit of HC/FMUSP, in conjunction with the Department of Neurosurgery of HC/FMUSP and the Laser Medical Center at the Incor of HC/FMUSP. All congenital lesions were diagnosed in the prenatal period and were treated in accordance with the "time zero" protocol with surgical correction of MMC immediately after birth.

A total of 13 patients were prospectively studied. They underwent surgery for MMC immediately after birth and were submitted to preventive adjuvant therapy in the immediate postoperative period with LLLT. Two groups were evaluated and the Group A comprised patients treated from July 2007 to April 2008 with Diode Laser CW (DMC, Brazil) with the following 
parameters: $\lambda=685 \mathrm{~nm}, 21 \mathrm{~mW}$ power, applied along the incision, $2 \mathrm{~cm}$ apart, with a total of $0.19 \mathrm{~J}$ energy delivered in each point.

In this study, the incidence of incision fistula, dehiscence of surgical wound and postoperative infections (meningitis/ventriculitis) were compared to the retrospective data of 23 patients with MMC, also with surgical correction immediately after birth, by the same medical team, at the same sites, from June 2004 to December 2006, with no application of adjuvant laser therapy. They composed the Group B.

\section{RESULTS}

The epidemiological and surgical data observed showed similarity and homogeneity between the groups (Tables 1 and 2). In the great majority of cases (46.1\%), a single laser session was required (Figure $1 \mathrm{a}$ and $2 \mathrm{~b}$ ). However, when potential dehiscences were observed in the surgical wound, further doses were administered as shown in Table 3.

Table 1. Epidemiological data of both groups

\begin{tabular}{lcc}
\hline Population characteristics & Group A (LLLT) & Group B \\
\hline Number of patients & 13 & 23 \\
Male & 6 & 11 \\
Female & 7 & 12 \\
Birth weight (mean, g) & 2889 & 2944 \\
Maternal age (mean, years) & 24.8 & 23.2 \\
Prenatal diagnosis & $13(100 \%)$ & $23(100 \%)$ \\
Hydrocephalus & $6(46 \%)$ & $15(65 \%)$ \\
\hline
\end{tabular}

LLLT: Iow level laser therapy.

Table 2. Surgical data

\begin{tabular}{lcc}
\hline Defect characteristics & Group A (LLLT) & Group B \\
\hline Size of defect $\left(\mathrm{cm}^{2}\right)$ & & \\
Mean & 16.4 & 16.9 \\
Maximum & 36.8 & 80 \\
Minimum & 10.0 & 2.25 \\
Site of the defect & & \\
Thoraco-lumbar & 1 & 5 \\
Lumbar-sacral & 12 & 18 \\
Preoperative rupture & $6(60 \%)$ & $9(39 \%)$ \\
Surgical procedure & 12 & 21 \\
Direct closure & 12 & 21 \\
Skin flap & 1 & 2 \\
\hline
\end{tabular}

LLLT: low level laser therapy.

Table 3. Number of low-level laser therapy applications after neurosurgical procedure

\begin{tabular}{lc}
\hline Number of patients (\%) & Total LLLT applications \\
\hline $6(46.1)$ & 1 \\
$5(38.5)$ & 2 \\
$2(15.4)$ & 3 \\
\hline
\end{tabular}

LLLT: low-level laser therapy.

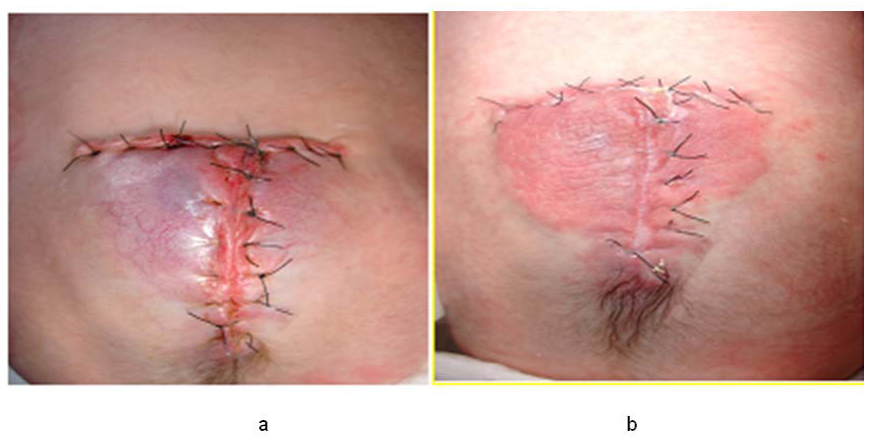

Figure 1. Immediate postoperative period (a) and 11 th postoperative day, after application of low-level laser (b)

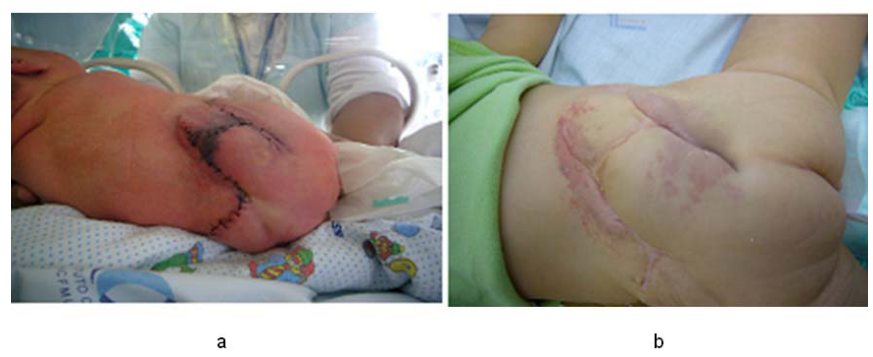

Figure 2. Neonate on the 2nd postoperative day after a single application of low-level laser during the immediate postoperative period (a) and follow-up of 12 months after surgery of myelomeningocele (b)

The surgical wound clinical course was followed up for 6 to 12 months, and it was possible to observe an extensive area of lesion treated immediately after surgery with LLLT (Figure 2a) and one year later (Figure 2b).

Among the complications identified up to 30 days after surgery, patients in Group A who underwent preventive therapy with LLLT showed a two-fold lower number of dehiscences as compared to Group B (7.69 versus $17.39 \%$, respectively). In addition, one patient in Group B evolved with dehiscence and required reoperation, as displayed in Table 4.

Table 4. Postoperative complications

\begin{tabular}{lcc}
\hline Complications & Group A (LLLT) & Group B \\
\hline Number of dehiscences & $1 / 13(7.6 \%)$ & $4 / 23(17.4 \%)$ \\
Minimal dehiscences & 1 & 3 \\
Major dehiscences requiring re-operation & 0 & 1 \\
Cerebrospinal fluid fistula & $1 / 13(7.6 \%)$ & $3 / 23(13 \%)$ \\
Surgical infection / meningitis & $1 / 13(7.6 \%)$ & $2 / 23(8.7 \%)$ \\
\hline
\end{tabular}

LLLT: low level laser therapy.

\section{DISCUSSION}

Neural tube defects have multifactorial causes, including genetic and environmentalfactors, with higherincidences in less favored social classes. The study carried out by the Latin American Collaborative Study on Congenital 
Malformations (ECLAMC), from January 2000 to August 2001, showed a mean prevalence of 2.4/1000 births in five Latin American countries ${ }^{(16)}$. Brazil had the highest rate (3.3/1000), followed by Argentina (2.6/1000) and Uruguay $(1.7 / 1000)^{(16)}$. According to Filgueiras and Dytz $^{(1)}$, MMC was the most prevalent defect $(91 \%)$, located especially in the lumbosacral region, which was also identified in a previous study (Group B).

Although low, the rate of dehiscence found in surgically corrected MMC in the last few years at the High Complexity Nursery at HC/FMUSP still represents a high percentage, with risk of cerebrospinal fluid fistula and meningitis. Morbidity, mortality and the functional prognosis in these patients are directly related to infectious complications; therefore, additional techniques to increase the surgical results are always welcome.

Suture dehiscence after surgical repair of the spinal defect could mean local infection and increased suture tension. Pang ${ }^{(17)}$ considered that extensive lesions are predisposing factors for dehiscence, infection and cerebrospinal fluid fistula. In this study, we found a similar mean size of surgical incisions between the groups (Table 2), with a maximum incision of $36.8 \mathrm{~cm}^{2}$ and a minimum of $10 \mathrm{~cm}^{2}$ in the group treated with laser, in which less morbidity was observed.

In the study carried out by Braga ${ }^{(18)}$ involving neonates with extensive spinal lesion (larger than $5 \mathrm{~cm}), 47 \%$ progressed with suture dehiscence of the surgical repair, $35 \%$ with cerebrospinal fluid fistula, $24 \%$ with central nervous system (CNS) infection and $6 \%$ with local infection. On the contrary, in the present study, $7.69 \%$ of the neonates who used LLLT evolved with dehiscence. However, a much higher percentage $(17.39 \%)$ of neonates who did not benefit from this adjuvant therapy developed dehiscence, with one case requiring reoperation of the dehiscent wound.

In vitro, LLLT demonstrated modulation of activity of several cells involved in the process of tissue repair, including macrophages, fibroblasts, keratinocytes, giant cells, lymphocytes and endothelial cells ${ }^{(19)}$.

In a study carried out by Pugliese et al. ${ }^{(10)}$, LLLT contributed to intense reduction of edema in the inflammatory infiltrate as well as increased vascularization, in addition to more production of collagen and elastic fibers during the healing process in animals. According to Bjordal et al., LLLT enhances angiogenesis by means of increased secretion of growth factor and formation of collateral vessels at the wounded region, in several studies of cells and animals during the first seven days after the injury ${ }^{(20)}$. In the present pilot study, the data pointed to a reduction in morbidity in infants after laser use in the first hours of immediate postoperative period; this also possibly accounted for promoting an efficient response in Group A.
Some local complications, such as infection, surgical suture dehiscence and cerebrospinal fluid fistula may postpone discharge from hospital. These abnormalities also represent an entry to systemic infection and particularly CNS infection, besides increasing the waiting time for ventricular bypass ${ }^{(18)}$. In this study we observed that LLLT acted as a biomodulator agent in the surgical wounds and it was able to reduce the complications, when compared to the group not treated with laser, thus aiding early healing of surgical incision in neonates and corroborating the results found by Bjordal et al. ${ }^{(13,20)}$.

In our study we verified that the overall rate of surgical wound dehiscence was lower in the group treated with laser therapy (Group A) as compared to Group B, which received only the routine conventional treatment at the Neonatal Unit. Laser therapy seems to be a new efficient treatment option associated with improved postoperative results, especially prevention of dehiscences or their relapses, aiming to obtain safe and noninvasive treatment responses. In this pilot study, the use of LLLT to increase tissue repair in surgical wound after surgical correction of MMC is proposed, with our results indicating a lower rate of surgical dehiscence. In this specific condition, appropriate healing response protects neonates from the risk of CNS infection, which could lead to sequelae and delayed neuropsychomotor development.

Future studies leading to ideal dose values may probably contribute to an even better prognosis to these patients. A follow-up of the patients in this study is necessary, since LLLT will still possibly bring additional long-term benefit, which would be a decreased rate of anchored spinal cord, thus avoiding new surgical interventions in the future.

\section{CONCLUSION}

The analysis in this study in neonates points to decreased incidence of surgical wound dehiscence after surgical correction of MMC, with preventive administration of LLLT. Laser proved to be an efficient adjuvant tool in the healing of surgical wound and seems to be a safe and noninvasive method, which may decrease hospital stay as well as be more cost-effective, both to patients and the institution involved.

\section{REFERENCES}

1. Filgueiras MG, Dytz JL. Avaliação do perfil de recém-nascidos portadores de defeitos do tubo neural. Brasília Med. 2006;43(1/4):17-24.

2. Pinto FCG, Alho E, Matushita H, Plese JPP. Tratamento cirúrgico imediato após o nascimento em pacientes portadores de mielomeningocele [abstract]. [Apresentado no $7^{\circ}$ Congresso da Sociedade Brasileira de Neurocirurgia Pediátrica; 2007 Maio; Curitiba. PR, Brasil]. 
3. Chavantes MC. Laser em Problemas Cardio-respiratórios. In: Chavantes MC, editor. Laser em Bio-Medicina. São Paulo: Atheneu; 2009. p. 149-81.

4. Kajita GT. Efeitos do laser de baixa potência no membro póssafenectomia em diabéticos submetidos à revascularização miocárdica [Mestrado]. São José dos Campos (SP): Universidade do Vale do Paraíba; 2002.

5. Shoji N. Estudo sobre o efeito do laser de baixa potência em deiscência da safenectomia pós-revascularização miocárdica [Mestrado]. São José dos Campos (SP): Universidade do Vale do Paraíba; 2003.

6. Luiz MCRA. Análise do efeito do laser de baixa potência no processo de reabilitação pós-reconstrução do ligamento cruzado anterior [Mestrado]. São José dos Campos (SP): Universidade do Vale do Paraíba; 2004.

7. Baptista IMC, Chavantes MC, Oliveira SA. O Laser de Baixa Potência pode prevenir deiscência incisional em esternotomia pós-cirurgia cardíaca? Rev Soc Bras Lase. 2006;3(13):10-6.

8. Pinto NC, Pereira MHC, Stolf NAG, Chavantes MC. Laser de baixa intensidade em deiscência aguda de safenectomia pós-revascularização miocárdica: proposta terapêutica. Rev Bras Cir Cardiovasc. 2009;24(1):88-91.

9. Pinto NC, Chavantes MC, Stolf NAG, Prevent complications in cardiovascular surgery: a successful method applying low level laser therapy [abstract]. [Presented at $28^{\text {th }}$ American Society for Laser Medicine and Surgery (ASLMS) Annual Conference; 2008 Apr 2-6; Kissimmee, Florida, USA].

10. Pugliese LS, Medrado AP, Reis SRA, Andrade ZA. The influence of low-level laser therapy on biomodulation of collagen and elastic fibers. Pesqui Odontol Bras. 2003;17(4):307-13.

11. Damante CA, Greghi SLA, Santana ACP, Passanezi E. Clinical evaluation of the effects of low-intensity laser (GaAIAS) on wound healing after gengivoplasty in humans. J Appl Oral Sci. 2004;12(2):133-6.

12. Karu T. Primary and secondary mechanisms of action of visible to near-IR radiation on cells. J Photochem Photobiol B. 1999;49(1):1-17.
13. Lopes-Martins RAB, Labat RL, Ramos L, Pallota RC, Penna SC, Bjordal JM. Novos paradigmas no processo inflamatório: possíveis mecanismos de ação da laserterapia de baixa intensidade e considerações sobre dosimetria. J Bras Laser. 2007;1(1):12-9.

14. Ailioaie C, Ailioaie L, Topoliceanu F. Self-organizing phenomena at membrane level and low-level laser therapy of rhinitis. In: Longo L, Hofstetter AG, Pascu ML, Waidelich WR, edithors. Laser Florence 99: A Window on the Laser Medicine World. Bellingham: SPIE; 2000. v. 4166, p. 309-15. [Proceedings SPIE].

15. Ailioaie C, Ailioaie LM, Chiran DA. Laser regeneration of nerve injuries triggered by low level laser therapy in children. OP1-05. [Abstract]. [Presented at $4^{\text {th }}$ International Congress of World Association of Laser Therapy; 2002 June 2730; Tokyo, Japan]

16. Castilla EE, Orioli IM, Lopez-Camelo JS, Dutra Mda G, Nazer-Herrera J; Latin American Collaborative Study of Congenital Malformations (ECLAMC). Preliminary data on changes in neural tube defect prevalence rates after folic acid fortification in South America. Am J Med Genet A. 2003;123A(2): 123-8.

17. Pang D. Surgical complications of open spinal dysraphism. Neurosurg Clin $N$ Am. 1995;6(2):243-57.

18. Braga MA. Resultado neonatal na espinha bífida de acordo com marcadores do ultra-som obstétrico. [Dissertação de mestrado]. Botucatu: Universidade Estadual Paulista; 2002.

19. Agaiby AD, Ghali LR, Wilson R, Dyson M. Laser modulation of angiogenic factor production by T-lymphocytes. Lasers Surg Med. 2000;26(4): 357-63.

20. Bjordal JM, Johnson MI, Iversen V, Aimbire F, Lopes-Martins RAB. Low-level laser therapy in acute pain: a systematic review of possible mechanisms of action and clinical effects in randomized placebo-controlled trials. Photomed Laser Surg. 2006;24(2):158-68. 